\title{
Spatial variability in the timing, nature and extent of channel response to typical human disturbance along the Upper Hunter River, New South \\ Wales, Australia
}

Joanna Hoyle ${ }^{1^{\star}}$, Andrew Brooks ${ }^{2}$, Gary Brierley ${ }^{3}$, Kirstie Fryirs ${ }^{1}$ and James Lander $^{1}$

* Contact author: email jhoyle@els.mq.edu.au, ph: +61 404399388, fax: +61 2 98508420

${ }^{1}$ Department of Physical Geography, Environmental Life Sciences, Macquarie University, NSW, 2109, Australia

${ }^{2}$ Centre for Riverine Landscapes, Griffith University, Nathan, Queensland, 4111, Australia

${ }^{3}$ School of Geography, Geology and Environmental Science, University of Auckland, Auckland, New Zealand

\begin{abstract}
Prior to European settlement the Upper Hunter River near Muswellbrook, New South Wales was a passively meandering gravel-bed river of moderate sinuosity and relatively uniform channel width. Analyses of floodplain sedimentology, archival records, parish maps and aerial photographs document marked spatial variability in the pattern of channel change since European settlement in the 1820s. Different types, rates and extents of change are reported for seven zones of adjustment along an $8 \mathrm{~km}$ study reach. This variable adjustment reflects imposed antecedent controls (buried terrace material and bedrock), which have significantly influenced local variability in river sensitivity to change, as well as contemporary morphodynamics and geomorphic complexity. Local variability in system responses to disturbance has important implications for future river management and rehabilitation.
\end{abstract}




\section{Key words}

River change, human impacts, sensitivity, lagged responses, within-reach variability

\section{Introduction}

An understanding of past disturbance response and local sensitivity is a prerequisite for assessing recovery potential and predicting how a reach may respond to future disturbance. These are critical considerations for effective river management and rehabilitation planning. While disturbance to river systems, be it natural or human-induced, is recurrent, the morphological manifestation is often not uniform. This is because the distribution, character and intensity of erosional and depositional processes tend to vary along a river, given the variable capacities of reaches to adjust to and absorb disturbances (Brierley and Fryirs, 2005; Brunsden and Thornes, 1979; Thomas, 2001; Werrity and Leys, 2001). Existing geomorphic literature typically focuses on the sensitivity of particular rivers or reaches in terms of the timing, magnitude or nature of response to various disturbances. Disturbance events may induce fundamental and persistent morphological changes over long reaches and very short timeframes in sensitive landscapes, a process sometimes referred to as river metamorphosis (Brooks and Brierley, 1997; Brooks and Brierley, 2000; Erskine, 1986; Schumm, 1969). In contrast, resistant rivers are insensitive to imposed disturbances and absorb the impacts of perturbations with only minor adjustments to their configuration over considerable timeframes.

A wide range of variables preconditions the sensitivity or resistance of a reach for channel change. Spatially, factors such as sediment supply, planform configuration, channel gradient, hydraulic resistance of the bed and bank induced by vegetation and wood, and bed and bank material texture, influence the sensitivity of a reach to change (Brunsden and Thornes, 1979; Downs and Gregory, 1993; Hickin, 1983). Temporally, the proximity to a threshold of 
instability may dictate the magnitude and timing of adjustment to a given disturbance (Brooks et al., 2003; Chappell, 1983; Harvey and Watson, 1986).

Lagged response and variability in the timing and magnitude of channel adjustment to imposed disturbances are persistent themes in fluvial geomorphology. Lagged response to disturbance is often explained in terms of the recurrence of floods of a given magnitude and duration that exceed the threshold conditions lowered by a disturbance (eg. Schumm, 1979). It can also be examined in the context of a sequence of floods that magnifies the response of individual floods (Costa and O'Connor, 1995; Nanson, 1986; Newson, 1980). In south eastern Australia multi-decadal cycles in the flood regime, known as flood and drought dominated regimes (FDRs and DDRs), have been invoked to explain channel change in some rivers (Erskine and Warner, 1988; Warner, 1987). While it has been demonstrated that these secular climatic phases do not represent the ultimate cause of channel metamorphosis in south eastern Australia over the last 200 years (Brooks and Brierley, 1997; Brooks and Brierley, 2000; Brooks et al., 2003), they may account for lagged responses, particularly in circumstances where the disturbance occurs within a DDR and several decades pass before floods of an appropriate magnitude cause the necessary threshold exceedance and geomorphic response. Furthermore, there is little doubt that in the post-disturbance period, such flood and drought phases exert a strong bearing on channel morphodynamics.

It is now clear that European settlement of Australia in the late $18^{\text {th }}$ and early $19^{\text {th }}$ centuries significantly altered fluvial dynamics in many rivers (Brooks and Brierley, 1997; Olley and Wasson, 2003; Prosser et al., 2001). For two thousand years prior to European settlement rivers in coastal south eastern Australia were characterised by relative geomorphic stability (Nanson and Doyle, 1999). Large scale channel adjustments such as lateral migration were rare and overbank deposition of fine material dominated (Rustomji et al., 2006). Hydraulic roughness was high as a result of well vegetated riparian zones and instream 
large woody debris (Brooks et al., 2003). Following European settlement, unprecedented channel change resulted from a combination of riparian vegetation and wood removal (Brierley et al., 2005; Brooks et al., 2003), and impacts of stock (Magilligan and McDowell, 1997; Trimble and Mendel, 1995). In some systems, enhanced channel capacity and reduced instream roughness has markedly increased the geomorphic effectiveness of floods (sensu Wolman and Gerson, 1978), as floods of a higher magnitude are retained within the enlarged channels (Brooks and Brierley, 2004). Given current rates of sediment supply and transport in these systems, it will take thousands of years for these rivers to recover to their pre-disturbance dimensions (Brooks and Brierley, 2004; Fryirs and Brierley, 2001).

Catastrophic change to rivers in south eastern Australia, however, has not been universal and existing studies give us an incomplete view of river sensitivity in this region. The nature and rate of river responses to European settlement disturbance has varied markedly across space and time (Rutherfurd, 2000). This may reflect differences in the extent and intensity of human impacts, and/or inherent variability in the sensitivity of river systems to disturbance. Attention has been given to investigating spatial patterns of adjustment in this region, including identifying 'river styles' of varying sensitivity (Brierley \& Fryirs, 2005), however studies rarely consider local, within-reach $(<1 \mathrm{~km})$ variability. As processes operating at this scale may be critical to ecosystem functionality (e.g. Fisher, in press; Poole, 2002), improved understanding of local sensitivity and disturbance response is needed for effective river management and rehabilitation planning (cf. Graf, 2000).

The Hunter River in New South Wales has been the focus of considerable research and enquiry into the nature of post-European river channel changes, commencing with several government enquiries in the mid C19th (eg. Moriarity, 1870) and continuing to more recent times (eg. Erskine, 1985, 1986, 1992; Erskine et al., 1985; Raine and Gardiner, 1995). Most research has focused on 
the Mid-Lower Hunter, as this is where the greatest change has occurred. Change in these lower reaches has typically been rapid (within two decades of disturbance) and extensive (Erskine, 1986). The Mid-Hunter River at Singleton is today four times its pre-European width (Gardiner, 1991). Subsequently, the Hunter River has been subjected to more river training works than any other river in New South Wales (Erskine, 1992). In this study we investigate the variability in channel response to relatively uniform, and typical, disturbance of the riparian and in-channel zone along an $8 \mathrm{~km}$ reach of the Upper Hunter River, near Muswellbrook. We analyse the timing, magnitude and nature of post-European settlement disturbance response at the within-reach scale. This is framed in light of longer term (Late Holocene) river changes along the study reach. Implications for river management and rehabilitation are then explored.

\section{Reach Setting}

The Hunter Valley is the third largest coastal catchment in New South Wales, draining an area of approximately $22,000 \mathrm{~km}^{2}$ (Figure 1 ). The section of river upstream of the Goulburn River confluence is known as the Upper Hunter River. The study reach, located $5 \mathrm{~km}$ south-west of Muswellbrook, drains an area of $4220 \mathrm{~km}^{2}$. Glenbawn Dam, $11 \mathrm{~km}$ upstream of Aberdeen, was completed in 1958 and captures approximately $30 \%$ of the catchment upstream of the study reach, with a sediment trap efficiency of approximately 98.9\% (Erskine, 1985; Erskine, 1992). Three main tributaries join the Hunter between Glenbawn Dam and the study reach, namely Rouchel Brook, Dart Brook and the Pages River. Rouchel Brook and its tributaries are bedrock controlled, indicating that they supply very little bedload or suspended load sediment. Studies elsewhere in the region indicate that most suspended and bedload sediment is sourced from bed and bank erosion rather than hillslopes Fryirs and Brierley, 1999; Olley and Wasson, 2003; Wasson et al., 1996). Dart Brook is a low slope, low capacity, highly sinuous, entrenched stream with cohesive banks and very little gravel bedload. Pages River is the largest tributary and has undergone significant incision and 
channel expansion since European settlement. The Lower Pages River is transport limited and a sediment slug extends more than $8 \mathrm{~km}$, almost to its confluence with the Hunter (Fryirs et al., in press). This slug is a potential future sediment source to the Hunter River.

Rainfall around Muswellbrook averages $600 \mathrm{~mm} / \mathrm{yr}$, whereas annual averages in the adjacent Barrington Tops and north-eastern mountains of the upper catchment exceed 1,400 mm/yr. Monthly maximum discharge data for the Hunter River at Muswellbrook are available from 1907 (Figure 2a). This record has been augmented with additional archival information about the stage heights of significant floods since 1857 and the flood record was extended back to 1806 using data extrapolated from the Maitland and Singleton gauges (NSW Water Resources Commission, 1984). These data are presented in Figure 2(b), with all floods converted to equivalent gauge heights at the Muswellbrook Bridge gauge. The 1955 flood is the largest flood recorded at the Muswellbrook gauge and is considered to be the 1:100 year event. Compiled records indicate that the flood of June 1820 may have reached approximately the same levels as the 1955 event and the 1806 and 1870 events may have exceeded the 1955 levels (NSW Water Resources Commission, 1984), albeit under different channel conditions.

The irregular occurrence of floods is evident from Figure 2(b). Warner (1987) and Erskine and Warner (1988) identified DDRs between 1821-1856 and 1901-1948, with FDRs delineated from 1857-1900 and again since 1949. Subsequent analysis has shown that the system shifted to a new DDR between April 1976 and June 1977 (Cohen, 2003). Within these periods there is also a degree of variability. A series of large floods between1857-1875 and 1893-1900, both within the same FDR, are interspersed with recurrent floods of small to moderate magnitude and extensive periods with no major flooding. Contemporary morphological bankfull discharge, averaged from 53 cross sections along the study reach, is approximately $1700 \mathrm{~m}^{3} / \mathrm{s}$, with a recurrence interval of 14 years (with a range of 8 to 21 years). Under the current flow regime, river flows are $<12$ 
$\mathrm{m}^{3} / \mathrm{s}$ for $90 \%$ of the time, and $<1 \mathrm{~m}^{3} / \mathrm{s}$ for $10 \%$ of the time (Figure $2 \mathrm{c}$ ). The closure of Glenbawn Dam has resulted in increased low flows and decreased peak flows.

The Lower to Mid Hunter Valley was settled by Europeans between 1812 and 1820. Settlement of the Upper Hunter Valley commenced in the mid 1820's. Until 1836 (at least) the banks and the floodplain of Lower Hunter at Maitland remained densely vegetated by forest. Logging and subsequent floodplain farming resulted in the removal of virtually all riparian vegetation as well as instream wood along the Mid to Lower sections of the Hunter River by the mid C19th (Raine and Gardiner, 1995; Rankin, 1982). Mr Alexander Munro stated in 1869 that, when he arrived in Singleton (Mid Hunter) in 1830, there were a great many oaks on the banks of the river and growing in the channel, but these were gone by 1857 (Moriarty, 1870). Between 1832 and 1857 the Mid-Lower reaches of the Hunter showed signs of significant change in channel planform and geometry. Channel widening, bank erosion and cut-offs were characteristic between the mid C19th and early C20th. The Hunter River at Singleton doubled in width between 1841 and 1969 (Moriarty, 1870). Today it is four times its preEuropean width (Gardiner, 1991) and is sand dominated due to the input of extensive sandy bedload from the Goulburn River tributary (Figure 1).

\section{Methods}

\section{Determining pre-European river condition}

The condition of the Upper Hunter River prior to European settlement was determined using various archival data, including early explorers and settlers notes, surveyors' journals, diaries and books that contain descriptions of the physical condition of the landscape at the time of European settlement. A series of parish maps (electronic copies, originals 3 inches to the mile) dating back to 1883 show the channel planform. Historical reports were supplemented with analyses of floodplain and palaeochannel sedimentology, providing further 
evidence of river morphology and behaviour prior to European settlement. Former channel dimensions were interpreted from trenching and drill holes at three palaeochannels (the Kehua cut-off, Cow Trench cut-off and Bengalla Road palaeochannel; see Figure 1). Where available, charcoal was collected for $\mathrm{C}_{14}$ dating. The textural variability of floodplain sediment from seven auger holes, located on the outside of the meander bends, was analysed at $20 \mathrm{~cm}$ intervals using a Malvern Mastersizer.

\section{Determining the magnitude, nature and spatial variability in river change}

The study reach is characterised by clear spatial variability in macrochannel width (Figure 1). The degree of adjustment was measured by comparing contemporary cross section surveys and a $1 \mathrm{~m}$ LiDAR derived DEM against channel width indicated on the first parish map (1883). In order to compare various sub-reaches an arbitrary three tiered adjustment classification was established, firstly to differentiate between expanded and non-expanded zones, and then to look for differences in the extremes of expanded zones. These were termed low, intermediate and high adjustment zones, which respectively were designated to have expanded less than $25 \%, 25-150 \%$ and more than $150 \%$. Definition of sub-reaches was limited to a minimum length of $500 \mathrm{~m}$ (as measured along the low flow thalweg). This classification resulted in seven adjustment zones. The main geomorphic units (bars, benches and low flow channel variability) within each adjustment zone were characterised from field surveys and aerial photograph analysis. The number of geomorphic units per $\mathrm{km}$ of channel length was calculated as an indication of geomorphic complexity (Graf, 2006).

\section{Determining the timing of river change}

The timing of river change was determined from analysis of historical parish maps (1883-1938), aerial photographs (1938-2004) and records of engineering works carried out in the study reach (1963-2002). Historical parish maps and aerial photographs were used to examine the configuration of the macrochannel, 
the low flow channel and major geomorphic unit assemblages from 1883present. Parish maps used include: Parish of Clanricard (right bank) - 1883, 1897, 1921, 1938 and Parish of Brougham (left bank) - 1892, 1918, 1923. Whilst the resolution and precision of these parish maps was limited, and inconsistencies in the notation of features on some maps were evident, these resources provide invaluable information about channel alignment, and hence the nature and timing of river change. Stereographic interpretation and quantitative spatial analysis using GIS were completed for historical air photographs from 1938, 1952, 1955 (after the 1:100 year flood), 1958, 1967, 1969, 1974, 1979, 1982, 1989, 1998 and 2004.

In order to examine the influence of river works on contemporary river morphology, data on the location, type and date of river works were compiled from fortnightly progress reports held as historical records at the Scone Research Centre. Unfortunately, the data set is incomplete, as some documents have been destroyed (Elsley, 2005 Pers. comm.). Hence, the data presented underestimate the total number of works undertaken.

\section{Results}

The geomorphic character of the Upper Hunter River at the time of European settlement

Early explorer accounts of river morphology at the time of European settlement In 1824, Henry Dangar became the first European explorer to survey the valley above the confluence of the Goulburn and Hunter Rivers. These are the first descriptions of the Upper Hunter. At this time, flood debris was observed in the riparian vegetation up to 50-60 feet (15-18 $\mathrm{m}$ ) above the level of the low flow channel just upstream of the Goulburn confluence (Dangar, 1824). A year later, Allan Cunningham (1825) described elongate pools on the Upper Hunter immediately upstream of the Goulburn confluence as being too deep for packhorses to cross and not above 50 yards $(46 \mathrm{~m})$ wide. Riffles were also numerous (Cunningham, 1827). Peter Cunningham (Allan Cunningham's 
brother) gave detailed description of the area near Denman in 1827, saying "the flat alluvial lands spread out before you, being matted with luxuriant herbage; branching evergreens scattered singly or in irregular clumps; the river winding through the midst; whilst dark-foliaged swamp-oaks bordering with a deep-green fringe its steep and grassy banks, and the gently rising hills beyond, thinly clothed with wide spreading forest trees, extend in diversified magnificence as far as the eye can reach" (Cunningham, 1827: p145). Peter Cunningham also painted a vivid picture of the floodplain around Edinglassie (Figure 1), describing the land as "in all these luxuriant plains there is scarcely a superfluous tree to be seen, not often above a dozen to the acre; and patches of acres are here and there met with destitute even of one" (Cunningham, 1827 p146). The rising hills beyond were more densely populated with timber (Wood, 1972).

From this information it can be inferred that prior to European settlement, the middle and upper reaches of the Hunter River were characterised by a deep and gravel-based low flow channel with pools and riffles. Although historical sources do not state channel dimensions for the study reach, descriptions of the channel immediately upstream of the Goulburn River indicate that the channel here was significantly narrower than downstream of this confluence (Middle Hunter). Descriptions tell us the banks of the Upper Hunter were steep and densely vegetated and the floodplain was composed almost entirely of an open woodland or grassland association. Peake (2003) describes a floodplain forest dominated by Eucalyptus camaldulensis (river red-gum), Eucalyptus tereticornis (forest redgum) and Eucalyptus melliodora (yellow box). Riparian margins were typically lined with Casuarina cunninghamiana (river oak), and pockets of Toona cilliata (red cedar) likely existed in sheltered riparian locations.

Floodplain sedimentology and palaeochannel dimensions - insights into late Holocene channel and floodplain morphodynamics

Particle size analysis of the auger holes adjacent to each sub-reach (zone) shows the floodplains predominantly comprise silts and fine sands with average 
grain size ranging from 46 to $179 \mu \mathrm{m}$ (Table 1). Although upward fining sequences are evident within each sediment column, there are no clear patterns between sites. The relative uniformity of these deposits, and the lack of geomorphic indicators of lateral migration (such as scroll bars or lateral accretion deposits), indicates a long-term tendency for vertical floodplain accretion within the study area. $\mathrm{C}_{14}$ dates derived from floodplain deposits at $5.4 \mathrm{~m}$ depth, located adjacent to the Bengalla trench (Table 2 and Figure 3 ) yielded age estimates of 4,282 +/- 49 years BP (Wk 13664). Samples from $3.55 \mathrm{~m}$ and $2.95 \mathrm{~m}$ in the floodplain adjacent to Cow trench give age estimates of 1,307 +/-46 years BP (Wk 13663) and 1,263+/- 46 years BP (Wk 13662). Recognizing limitations of dating uncertainties and potential reworking of floodplain deposits, these age estimates indicate approximate rates of vertical floodplain accretion of1.3 - 2.7 $\mathrm{mm} / \mathrm{yr}$ in the mid-late Holocene (assuming a zero age at the surface, and acknowledging that this includes the post-disturbance depositional phase).

Three trenches through cut-offs and palaeochannels indicate that previous channel dimensions ranged from 75-110 m wide and up to $11 \mathrm{~m}$ deep (Figure 3). However, given that these trenches were excavated across the apex of bends, these measurements represent the upper limit of the widths and depths of the pre-European channel. The bedload material in the palaeochannels ranges in size from granule to pebbles and is notably more uniform than the contemporary channel, where bedload composition ranges from sand to large cobbles and occasional boulders (Hoyle et al., in press).

$\mathrm{C}_{14}$ dates from channel fill deposits at $0.98 \mathrm{~m}$ and $2.35 \mathrm{~m}$ in Cow trench returned ages of $261+/-42$ years BP and 2,210 +/- 38 years BP respectively (Wk 13660 \& Wk 13661). The latter date is considered to be reworked and unreliable (Blong and Gillespie, 1978), as it is considerably older than the adjacent floodplain deposits. This infers that the Cow trench cut-off occurred at some stage prior to 261 +/- 42 years BP, making it a pre-European settlement channel (and potentially of mid-Holocene age). Given its location and degree of infilling, the 
Bengalla palaeochannel is inferred to be considerably older than Cow trench cutoff.

Parish maps from 1883 show the Kehua cut-off (Figure 1) channel to be active. However, by the earliest aerial photograph in 1938 this section of channel has been cut off. Therefore, the Kehua cut-off is post-European and at least 70 years old. During this time there has been $3.5 \mathrm{~m}$ of channel fill.

\section{The contemporary character of the Upper Hunter River}

The contemporary study reach comprises an alluvial low-moderate sinuosity gravel-bed river with a moderately well defined pool-riffle sequence. Along most of the study reach, the low flow channel is inset within a macrochannel. The low flow channel thalweg ranges in depth from $0.5 \mathrm{~m}$ to over $3.5 \mathrm{~m}$ and varies between $10-40 \mathrm{~m}$ in width. Materials comprising the bed, bars and benches tend to be non-cohesive sands and gravel. Despite its appearance as a selfadjusting channel within a relatively wide, laterally unconfined valley (Figure 1), the character and behaviour of the Upper Hunter River are constrained by a range of inherited landscape controls. The floodplain comprises up to $10 \mathrm{~m}$ of cohesive fine-grained (silty clay to fine sand) materials (Table 1) overlying an extensive, partially indurated basal gravel and gravely sand. Bank exposures along much of the reach reveal various former terrace features, some of which are buried, comprising partially indurated sediments (including prior bedload gravels) (Figure 4). This terrace material often sits atop bedrock, which abuts the channel margins, on both the bed and banks, in a number of locations, but with greater control along the left bank. Average channel gradient of the study reach is 0.0014 .

While the low flow stage channel retains a relatively uniform width throughout the study reach, the macrochannel width ranges from 75-600 m, with variable assemblages of inset geomorphic units (Figure 5). Zones 4 and 6 have a 
macrochannel width of around $75 \mathrm{~m}$ (Figure 5). These dimensions are remarkably similar to the size of the pre- European channel indicated by the palaeochannel and cut-off trench sedimentology. These low adjustment zones are characterised by elongate pools within straight reaches that extend up to $1.2 \mathrm{~km}$ long and have limited geomorphic complexity (average of 1.7 units $/ \mathrm{km}$ ). As noted on Figure 4, lateral controls along the length of these reaches has induced low sensitivity to geomorphic change, such that the original planform alignment and cross sectional geometry of these zones has been maintained. These sub-reaches contrast starkly to zones 1, 3 and 7 that have channel width in excess of $300 \mathrm{~m}$ and are characterised by major channel cut-offs, significant bar deposits and very wide benches. These high adjustment zones have an average geomorphic complexity of 8.8 units $/ \mathrm{km}$. These zones were the most sinuous at the time of European arrival and contain little evidence of lateral controls. Zones 2 and 5 have channel widths between $150 \mathrm{~m}$ and $300 \mathrm{~m}$. These zones of intermediate adjustment contain benches that are, generally, not as wide as the bar deposits. The bar units tend to be more complex than in the high adjustment zones. These zones have an average geomorphic complexity of 10.8 units $/ \mathrm{km}$ and typically have lateral control on one bank and have expanded on the other.

Today the riparian margins are dominated by willows, herbaceous weeds and grasses with pockets of remaining and regenerating river oaks (Casuarina cunninghamiana). Native grasses, Themeda australis (kangaroo grass) and Danthonia sp. (wallaby grass), are restricted to areas with little agricultural modification. Cropping and intensive agriculture are conducted primarily on the floodplain with grazing on the surrounding hill slopes. Block diagrams presented in Figure 6 show the nature and extent of post-European channel changes in low, intermediate and high adjustment zones.

\section{Timing and nature of channel response to disturbance in the study reach}

Despite the presence of numerous palaeochannels (Figure 1), indications are that the system at the time of European settlement was a passively meandering 
channel (sensu Richards, 1982) with relatively uniform channel dimensions. Palaeochannel data indicate that the channel was narrow, with less variability in width than the contemporary macrochannel. Studies elsewhere (eg. Brooks et al, 2003) indicate that bed form variability (and hence form roughness), along with wood and vegetation roughness, would have been substantially higher than today.

European settlement (1820's) to 1897

The earliest Parish map of the reach, dating from 1883, and the subsequent 1892 map show a moderately sinuous channel (reach length thalweg sinuosity was 1.94) of narrow and relatively uniform width (Figures 6 and 7). The sinuosity varied significantly along the reach with the low adjustment zones being least sinuous and the high adjustment zones most sinuous (Table 1). The channel width on these maps is consistent with the palaeochannel widths, suggesting that the palaeochannels are reliable indicators of pre-European settlement channel dimensions. These maps also indicate that there was little change to the channel morphology during the first 70 years of settlement, despite large floods in 1832, 1857 and 1867 that caused significant changes along the Middle and Lower Hunter. By 1897, bends in Zone 3 and Zone 7 had widened and were characterised by altered patterns of sedimentation (i.e. large gravel accumulations and bars) (Figure 7).

1897-1938

All non-engineered cut-offs occurred prior to the first set of air photographs in 1938. Subsequent to cut-off formation, the study reach experienced a phase of macrochannel expansion and localised low flow channel realignment. The parish maps indicate that the majority of expansion occurred between 1918 and 1938. The expansion was most pronounced along the tightest bends within the most sinuous subreaches. This resulted in the formation of the intermediate and high adjustment zones (Figures 5 and 7). The 1938 aerial photographs show that although the macrochannel had significantly widened, the surfaces within the 
macrochannel were of relatively high elevation. This indicates that significant deposition within the macrochannel occurred following expansion (forming benches) or that the expansion did not mobilise material to the depth of the low flow channel across the entire macrochannel, leaving ledges (sensu Brierley and Fryirs, 2005).

\section{8-1955}

Further expansion of the macrochannel after 1938 has been negligible, despite the lack of riparian vegetation (Figure 8) and the occurrence of the 1:100 year flood in 1955. Between 1938 and 1955 geomorphic adjustment involved the mobilisation and reworking of sediments stored within the macrochannel. The 1955 aerial photographs (taken after the February flood) show a channel stripped of deposits, with wide but low elevation bars and few benches. Notable shifts in the alignment and sinuosity of the low flow channel are evident.

Quantitative spatial analysis of aerial photographs, using GIS to measure the surface area of geomorphic units as a ratio of macrochannel area, highlights various phases of erosion and deposition within the macrochannel (Table 3). Since 1938 there has been minor enlargement of the macrochannel and shortening (i.e. straightening) of the low flow channel. In 1938 the macrochannel was comprised primarily of benches with few bars (mostly compound lateral and compound point bar features). The 1:100 year event in 1955 caused significant erosion of benches, resulting in an increase in the surface area of compound point bars and a corresponding reduction in bench area (Table 3).

\section{5-present}

Since 1955 there has been an increase in bench area and a corresponding decrease in bar area. This indicates a transition in river behaviour towards net deposition. This transition occurred in the 1970's and is presented in the 1979 timeslice in Figure 7. During this period the river was also subjected to extensive sand and gravel extraction. The annual excavation rate from the Upper Hunter 
was estimated in 1983 to be about 200,000 tonnes, a rate that greatly exceeded the rate of replenishment by bedload transport (Erskine, 1985).

The contemporary channel within the study reach appears to be incised into a basal gravel lag by up to $4 \mathrm{~m}$ in places or locally sits on bedrock. However, the evidence for wholesale channel incision is equivocal. Palaeochannel dimensions indicate that pre-European channel depths are similar to the present day, and exposed basal lags can be explained by lateral erosion into former bar deposits. Rating curve changes at the Muswellbrook gauge (6.2 km upstream of reach) suggest there has been up to $0.75 \mathrm{~m}$ of incision between the late $1950 \mathrm{~s}$ and 1985 (Erskine, 1992). However, analysis of data over a longer time series shows that the bed level in the early twentieth century was roughly similar to the present day, and that there was a major aggradational phase $(+1 \mathrm{~m})$ in the 1950 s followed by degradation to the mid 1980s, and some aggradation since then (Shellberg and Brooks, unpublished data). Local incision has certainly occurred in association with artificial channel straightening, which shortened channel length by more than $10 \%$, but the expression of this incision is highly localised. Bed armouring and bedrock exposure, both downstream of, and within the study reach, make further incision unlikely.

Following the 1955 flood, a concerted effort was made to control erosion and increase channel stability. Pilot channels (river straightening) and bank control structures were installed to 'stabilise' the channel and establish smooth, open flow. A total of 260 river works, classified into eleven types, were installed along the study reach between 1963 and 2002 (Figure 4). Most of these entailed the removal of live and dead vegetation (i.e. desnagging, lopping and burn off). Follow-up works, aimed at repairing, replacing and maintaining the original works, make up a large proportion of the works. Planting of willows, river oaks and poplars was regularly undertaken until 1996. No bed control structures were installed along the reach. The density of works in the low adjustment zones is less than half that of the high and intermediate zones (Figure 4), reflecting the 
greater degree of channel adjustment in zones of higher sinuosity. Implementation of works was generally reactive, as they were applied after most channel changes had already occurred (Spink, 2006). The reduction in the density of works over time is in line with the level of historical channel adjustment. Enhanced stability of bar and bench features brought about by instream engineering works and associated willow planting programs has resulted in little adjustment in the location of the low flow channel since 1974 (Raine and Gardiner, 1994), effectively "pinning" it in place. Low flow thalweg sinuosity is now 1.74 .

\section{Discussion}

River systems, and local sections of any given system, have variable capacities to absorb the impacts of disturbance events. Despite the relatively uniform nature of human impacts along rivers following European settlement of south eastern Australia, pronounced spatial variability in the pattern, rate and extent of system response to disturbance is evident (eg. Rutherfurd, 2000). This study demonstrates that there is marked variability in the timing, nature and extent of response to European settlement disturbance in the Upper Hunter relative to the Mid and Lower Hunter, and that there is also significant variability at a much more localised scale, within a short $(8 \mathrm{~km})$ reach.

\section{The Upper Hunter relative to the Mid-Lower Hunter: Variable timing, nature and extent of geomorphic responses}

Although the Upper Hunter was settled only a decade after the Mid-Lower Hunter, it appears not to have demonstrated appreciable channel response for at least 70 years. This is despite the fact that channels were subjected to an equivalent disturbance history to that experienced downstream and that four sizable flood events, which caused widespread damage in the Middle and Lower Hunter, occurred between 1854-1875. The 1955 event also caused significant channel widening in the Mid-Lower Hunter, whereas in the Upper Hunter study 
reach macrochannel widening had essentially finished by this stage. Despite the range of geomorphic adjustments experienced along the study reach of the Upper Hunter River, including pronounced channel expansion at local (subreach) scales, overall changes have been less extreme than those documented along the Mid-Lower Hunter River. In summary, downstream of the Goulburn River confluence, the disturbance response began earlier, continued for longer and was more extreme, indicating a more sensitive landscape than the Upper Hunter. The prominence of non-cohesive sandy materials in the Middle and Lower Hunter may have predisposed these areas to erosion. Also, variability in the nature and timing of channel adjustments may reflect regional variability in flood history and cumulative responses along the Lower Hunter.

\section{Influences on the timing of changes in the study reach}

Changes in climatic regime, individual floods or sequences of floods, removal of riparian vegetation and large woody debris, changes in sediment supply, Glenbawn Dam and engineering works have all played a part in the timing of changes in the study reach. A conceptual model is presented in Figure 9 showing the timing of these various influences and the associated macrochannel response.

The Upper Hunter was settled in the mid 1820's and, as inferred from the MidLower Hunter, systematic clearance of riparian vegetation would have quickly followed to support agriculture and the raising of stock, along with ad-hoc desnagging programs for flood mitigation purposes (Moriarity, 1870; Raine and Gardiner, 1994). At the time of European settlement, the Hunter was in a drought dominated regime. Despite this, significant change in channel planform and geometry occurred in the Mid and Lower reaches of the Hunter between 1832 and 1857. Significant floods in 1857 (start of flood dominated regime), 1867, 1870 and 1874, all caused extensive changes in the Mid-Lower Hunter. However, available evidence indicates that there was little change within the study reach during this period. There is no evidence to support upstream 
progression of degradational influences; indeed, bedrock impediments likely preclude such a scenario.

The lack of evidence for major geomorphic adjustments in the Upper Hunter in response to large floods in the mid C19th indicates substantial internal resistance of this system to change. The period after the 1874 event was characterised by only minor flood events. The first phase of geomorphic response to disturbance occurred between 1883 and 1897, an interval characterised by a number of floods, none of which had a peak discharge as large as those that occurred between 1857 and 1870 . The trigger for change is likely to have been the 1893 flood, the largest event during this period. The fine-grained and cohesive nature of the banks may have been a significant factor in the geomorphic stability of the system. However, this does not explain why the system resisted changes during the earlier and larger floods. It is proposed that while land use changes may have pushed the Upper Hunter River closer to a geomorphic threshold, this was only breached when sufficient vegetation and wood were removed and there was a flood or sequence of floods of an appropriate magnitude to activate change. By the time of the 1893 flood, after two more decades of settlement pressure, thresholds were breached along the sensitive zones.

Between 1918 and 1938 rapid expansion occurred in localised subreaches. This was likely the result of four events in close succession in the late 1920's to early 1930's. Interestingly, this is within a drought dominated regime (Figure 9). Channel expansion resulted in net instream erosion but by 1938 extensive bench areas indicate that the reach was in a phase of net deposition. The 1955 event caused minor additional macrochannel expansion and significant erosion of bench and bar sediment. Gravel mining also commenced during this period. The closure of Glenbawn Dam in 1958 severed upstream sediment supply and reduced flood flows. This, along with the commencement of engineering works in the 1960's, shifted the system back to a phase of net instream deposition. 


\section{Phases of morphodynamic change in the Upper Hunter study reach}

Various phases of channel adjustment in the study reach, and associated changes in morphodynamics, are summarised as a conceptual model in Figure 10. Prior to European settlement the most significant human disturbance to the Australian landscape was the periodic burning of vegetation, carried out by Aboriginal people as part of their standard land management practices (Dodson and Mooney, 2002; Prosser, 1990). However, there is no evidence to suggest that, within the last few thousand years at least, this or any other influence caused the degree of morphologic adjustment experienced in the study reach since European settlement. The channel filling and floodplain aggradation rates observed over the last few thousand years would appear to be too low to have completely infilled a macrochannel of similar magnitude to that observed today, had such a feature been associated with the sampled palaeochannels. It is inferred that the pre-European channel had limited ability to adjust laterally due to the cohesive nature of bank materials, the densely vegetated banks, and localised buried terraces and bedrock that constrained lateral movement. Hence, the planform of the river is considered to have been passive-meandering (sensu Richards, 1982). Although the pre-European system experienced low rates of lateral migration, it was prone to avulsion, resulting in the formation of palaeochannels, preserved as neck cut-offs and whole channel sections. The channel appears to have retained (or re-established) its moderately sinuous planform and a narrow and deep channel geometry following each avulsion event. Given the smaller capacity of the pre-European settlement channel, with its relatively high roughness (Figure 6), morphological bankfull discharge events would have occurred more frequently than they do today. Flood energy would have been readily dissipated across the floodplain, depositing suspended sediment, resulting in vertical accretion of floodplains and a deep, narrow channel within steep, cohesive banks. The channel would have transported smaller bedload as evidenced by bed materials found in the palaeochannels. 
Breaching of threshold conditions triggered localised cut-offs in zones with the highest sinuosity and least lateral control (Figure 10). Subsequent rapid channel expansion was restricted to localised subreaches, increasing width/depth ratios and resulting in altered morphodynamic relationships in those zones that were most sensitive to disturbance. Planform adjustments were accompanied by alterations to bed slope and limited localised incision, locally modifying flow energy. This erosion liberated fine-grained material from the floodplain, and also made coarse basal clasts available for mobilisation. The increased channel capacity confined larger events with greater peak energy within the macrochannel, disconnecting the channel from its floodplain. Sediment transport potential was increased. Expansion of the macrochannel increased the potential for local adjustments to zones of erosion and deposition. As the low flow channel was no longer bounded by densely vegetated, steep and cohesive banks, the low flow channel was able to rework materials into various bar and bench forms. By 1955 channel capacity in the adjusted zones had increased by at least 50 - 300 $\%$. This channel enlargement resulted in an increase in sediment supply (initially) and storage capacity (now). Prior to the installation of engineering works, the low flow channel was freely adjusting within the widened macrochannel, reworking bedload materials. The relatively high rates of recent cut-off channel filling likely reflects the combined impact of increased sediment supply at the catchment scale, coupled with the fact that most contemporary deposition occurs within the confines of the macrochannel.

Riverworks began in the 1960's but the major phase of expansion had essentially ceased by 1938. Hence, these works had little effect on macrochannel expansion. Although the engineered cut-offs, channel straightening and sand and gravel extraction could have triggered further incision, this was likely mitigated by bedrock and natural armouring of the bed. In the period prior to 1978 there was little, if any, vegetation or woody debris left in the channel to impede flow (Figure 8). Increased within-channel roughness, associated with progressive weed encroachment and willow planting (usually in combination with steel pole and 
mesh fencing revetment works) in the 1960's, coincided with the closure of Glenbawn Dam. These factors enhanced stability of bedload deposits and likely contributed to the transition from net erosion to net deposition and the formation of large benches within the study reach. Fine grained materials that would previously have been deposited on the floodplain are now deposited within the enlarged macrochannel on bench and bar surfaces. This represents a fundamental change in river behaviour.

No systematic pattern or rate of adjustment can be discerned for the low flow channel. This is considered to reflect local hydraulic conditions, determined primarily by flow alignment (i.e. the sinuosity of any given bend), bend to bend configuration and the presence of lateral and vertical geological/geomorphic controls. As a result, there is pronounced down-reach variability in the type, pattern and extent of bar and bench features, inset geomorphic units and sediment organisation (Hoyle et al., in press). By the 1970's, geomorphic features within the macrochannel became stabilised and the low flow channel was pinned in place once more, returning the system to an alternative form of passive meandering.

The role of antecedent controls upon the extent and nature of river adjustment in the study reach

Prior to changes brought about by anthropogenic disturbance, the Upper Hunter River was relatively homogenous in its cross sectional area, with a somewhat irregular meandering planform. Despite the relatively uniform channel character, some sub-reaches were better able to resist the impacts of disturbance than others. The nature and rate of river response to human disturbance reflects sensitivity to change at the within-reach (zone) scale. In particular, the pattern of geomorphic adjustments correlates with channel sinuosity at the time of European settlement, as measured from the 1883 parish map (Figure 7). Similar findings are reported by Rinaldi (2003), who noted that the greatest degree of morphologic adjustment occurs where changes to sinuosity, and associated 
adjustments to channel bed slope, are at their maximum. The relative uniformity of fine-grained sediments that comprise the vertically accreted floodplain material in each zone indicates that the pattern and rate of channel expansion cannot be explained in terms of variable erodibility of bank sediments other than perhaps some variability in the basal bed material deposits. While there may have been some variation in the extent of clearing and desnagging and of stocking rates within the reach, the 1938 aerial photographs suggest disturbance pressures had been applied fairly intensively and uniformly across the whole reach by that time. Therefore there must be other reasons to explain the variability in sub-reach adjustment to the reach through time.

The variable extent of geomorphic change likely reflects the distribution of inherited controls within the study reach (Figures 4 and 6). Bedrock outcrops and buried terrace deposits locally inhibit channel adjustment. Controls are often only on one bank and may be below low flow water surface. As such, they do not represent complete channel confinement but they certainly increase bank stability. The presence of terrace material and bedrock on the left bank (outside bend) of each pool in Zones 4 and 6 (extending approximately $1000 \mathrm{~m}$ in each case) controls the consistent alignment of the pools and the apparent association with low adjustment zones. In contrast, the high adjustment zones that have experienced extensive geomorphic change have significantly less lateral control and were the most sinuous zones at the time of European settlement. In a sense, sinuous zones reflected a predisposition to morphologic adjustment (a form of geomorphic imprint, Thomas, 2001) as the pre European sinuosity reflected the distribution of these inherited controls.

\section{Implications for management and future rehabilitation planning}

Most studies of river responses to disturbance have focused on gross reachaveraged adjustments, rather than considering within-reach variability. However, this study indicates that an understanding of adjustments at both scales is necessary to appreciate variable sensitivity and therefore ensure effective 
management. While principles of hydraulic geometry describe systematic downstream increases in channel dimensions (Leopold and Maddock, 1953), these relationships mask local- and reach-scale variability. Plots of downstream trends in variables such as channel width commonly exhibit scatter which can vary by an order of magnitude either side of the trend line (eg. Knighton, 1998). While these first order trends are critical for deriving geomorphic theory, understanding the second order controls that explain scatter around the trend are likely to be of equal importance to river managers developing rehabilitation and management strategies at a scale that is practical for on-ground activities. Considerable amounts of money can be wasted stabilising sections of river that don't need stabilising and vice versa. For instance rock revetment and willow planting was carried out in the low adjustment zones of the study reach in the 1990's (Figure 4). This study shows that mapping of geomorphic controls, along with analysis of variability in downstream channel width and channel capacity, would potentially have helped river managers understand the differential sensitivity of some reaches to disturbance, prospectively saving large amounts of money that were spent on river works that were probably unnecessary.

Knowledge of the pre-European condition provides a key template with which to appraise geomorphic alterations to the Hunter River system. Understanding the within-reach variability in geomorphic responses to disturbance aids our interpretation of river sensitivity/resistance, aiding prediction of how the river may behave in the future. While it is probable that there was an initial spike in sediment supply, particularly prior to the closure of Glenbawn Dam, the current limited supply of bedload material from the upper catchment means that prospects for geomorphic recovery (i.e. macrochannel infilling) are slight over management timeframes (as noted by Brooks and Brierley, 2004).

Contrary to many studies which have demonstrated significant homogenisation of channel morphology as a result of anthropogenic disturbance (e.g. Brierley et al., 1999), this section of the Upper Hunter may have developed a more complex 
morphology following disturbance. Increased complexity is, however, unlikely to have been applied equally to all aspects of the system. For example, it is possible that the channel long profile has been homogenised with the removal of wood from the channel (sensu Brooks et al., 2003), whereas the complexity of inchannel bars and benches is likely to be much greater now than in the preexisting system. These changes in geomorphic complexity may significantly impact on aquatic and riparian ecosystem processes and dynamics, with greater prospects for ecological recovery in some zones. Understanding these linkages is vital for rehabilitation planning (Brierley et al., 2005; Wolfenden et al., 2005). Sub-reach scale geomorphic variations present major variations in aquatic and riparian habitat (eg. Downes et al., 1995). Ideally, this intra-reach variability should be incorporated into rehabilitation design principles, rather than uniform engineered channel dimensions based on the predicted hydraulic geometry.

\section{Conclusion}

This study has demonstrated significant variability in the timing, nature and extent of geomorphic response to European settlement at both the reach and within-reach scale. The Upper Hunter River is a less sensitive system than the Mid-Lower reaches which is most likely to be a function of different bed and bank sediments. Variable macrochannel expansion has been associated with the presence of localised antecedent controls. As local variability has important implications for ecological processes, understanding spatial variability at this scale may be fundamental for future river management and rehabilitation.

\section{Acknowledgements}

We are extremely grateful to all those who have given their support with this research. Particular thanks to Sarah Mika, Dan Keating, Mark Sanders and Tim Cohen for their support, advice and constructive comments, John Spencer for help with computer applications and Amalia Short for help in the field and with processing of historical riverworks data. Sincere thanks to the UHRRI sponsors and local landowners for their support and unlimited access to the Hunter River 
study site. This work is funded by an Australian Research Council Linkage Grant (LP0346918) with support from the following industry partners; Macquarie Generation, Bengalla Mine, Mt Arthur Coal, Department of Natural Resources, Department of Lands and Hunter and Central Rivers Catchment Management Authority. 


\section{References}

Blong RJ, Gillespie R. 1978. Fluvially transported charcoal gives erroneous 14C ages for recent deposits. Nature 271: 739-741.

Brierley G, Fryirs K. 2005. Geomorphology and River Management: Applications of the River Styles Framework. Blackwell Publishing: Oxford, UK.

Brierley, GJ, Cohen, T, Fryirs, K, Brooks, A. 1999. Post-European changes to the fluvial geomorphology of Bega Catchment, Australia: Implications for river ecology. Freshwater Biology 41: 839-848.

Brierley G, Miller C, Brooks A, Fryirs K, Boulton A, Ryder D, Leishman, M, Keating D, Lander J. 2005. Making integrative, cross-disciplinary research happen: Initial lessons from the Upper Hunter River Rehabilitation Initiative. In Proceedings of the Fourth Australian Stream Management Conference, Rutherfurd I, Wiszniewski I, Askey-Doran M, Glazik R (eds). Launceston, Tasmania; 125-133.

Brooks A, Brierley G. 1997. Geomorphic responses of lower Bega River to catchment disturbance, 1851-1926. Geomorphology 18: 291-304.

Brooks A, Brierley G. 2000. The role of European disturbance in the metamorphosis of lower Bega River. In River Management: The Australasian Experience, Brizga SO, Finlayson BL (eds). John Wiley \& Sons: London; 221-246.

Brooks A, Brierley G. 2002. Mediated equilibrium: the influence of riparian vegetation and wood on the long term character and behaviour of a near pristine river. Earth Surface Processes and Landforms 27: 343-367.

Brooks A, Brierley G. 2004. Framing realistic river rehabilitation targets in light of altered sediment supply and transport relationships: lessons from East Gippsland, Australia. Geomorphology 58(1-4): 107-123.

Brooks A, Brierley G, Millar RG. 2003. The long-term control of vegetation and woody debris on channel and flood-plain evolution: insights from a paired catchment study in southeastern Australia. Geomorphology 51: 7-29.

Brunsden D, Thornes JB. 1979. Landscape sensitivity and change. Transactions of the Institute of British Geographers 4(4): 463-484.

Campbell JF. 1928. John Howe's exploratory journey from Windsor to the Hunter River in 1819. Journal and Proceedings of the Royal Australian Historical Society 14: 232-241.

Chappell J. 1983. Thresholds and lags in geomorphologic changes. Australian Geographer 15(3): 357-366.

Cohen T. 2003. Late Holocene floodplain processes and post-european channel dynamics in a partly confined valley of New South Wales, Australia. PhD Thesis: University of Wollongong, Wollongong.

Costa JE, O'Connor JE. 1995. Geomorphically effective floods. In Natural and Anthropogenic Influences in Fluvial Geomorphology, Costa JE, Miller AW, Potter KW, Wilcock PR (eds). American Geophysical Union: Geophysical Monograph; 45-56.

Cunningham A. 1825. Expedition Journal: 11 April - 6 June. 
Cunningham P. 1827. Two Years in New South Wales. Henry Colburn: New Burlington St, London.

Dangar H. 1824. Traverse of Hunter River from Wollombi Brook to near the Isis River, Fieldbook.

Dodson J, Mooney S. 2002. An assessment of historic human impact on southeastern Australian environmental systems, using late Holocene rates of environmental change. Australian Journal of Botany 50(4): 455-464.

Downes BJ, Lake PS, Schreiber SG. 1995. Habitat structure and invertebrate assemblages on stream stones: A multivariate view from the riffle. Australian Journal of Ecology 20: 502-514.

Downs PW, Gregory KJ. 1993. The sensitivity of river channels in the landscape system. In Landscape Sensitivity, Thomas DSG, Allison RJ (eds). Wiley: Chichester; 15-30.

Erskine WD. 1985. Downstream geomorphic impacts of large dams: the case of Glenbawn Dam, NSW. Applied Geography 5: 195-210.

Erskine WD. 1986. River metamorphosis and environmental change in the Hunter Valley, New South Wales. PhD Thesis: University of New South Wales.

Erskine WD. 1992. Channel Response to Large-Scale River Training Works Hunter River, Australia. Regulated Rivers-Research and Management 7(3): 261-278.

Erskine WD, Geary PM, Outhet DN. 1985. Potential impacts of sand and gravel extraction on the Hunter River, New South Wales. Australian Geographical Studies 23: 71-86.

Erskine WD, Warner RF. 1988. Geomorphic effects of alternating flood- and drought-dominated regimes on NSW coastal rivers. In Fluvial Geomorphology of Australia Warner RF (ed). Academic Press: Sydney; 223-244.

Fisher S, Hefferman J, Sponseller R, Welter J. in press. Functional ecomorphology: Feedback between form and function in fluvial landscape ecosystems. Geomorphology.

Fryirs K, Brierley G. 1999. Slope channel decoupling in Wolumla catchment, South Coast, New South Wales, Australia: the changing nature of sediment sources since European settlement. Catena 35: 41-63.

Fryirs K. Brierley G. 2001. Variability in sediment delivery and storage along river courses in Bega catchment, NSW, Australia. Geomorphology 38: 237-265.

Fryirs K, Brierley G, Preston N, Spencer J. 2007. Catchment-scale (dis)connectivity in sediment flux in the upper Hunter catchment, New South Wales, Australia. Geomorphology 84: 297-316.

Gardiner JN. 1991. Hunter Region Environment Strategic Plan. NSW Department of Water Resources: Muswellbrook.

Graf WL. 2000. Locational probability for a dammed, urbanizing stream: Salt River, Arizona, USA. Environmental Management 25(3): 321-335.

Graf WL. 2006. Downstream hydrologic and geomorphic effects of large dams on American rivers. Geomorphology 79: 336-360. 
Harvey MD, Watson CC. 1986. Fluvial processes and morphological thresholds in incised channel restoration. Water Resources Bulletin 22(3): 359-367.

Hickin EJ. 1983. River channel changes: retrospect and prospect. International Association of Sedimentologists, Special Publication 6: 61-83.

Hoyle J, Brierley GJ, Brooks A, Fryirs K. (in press) Sediment organisation along the upper Hunter River, Australia: A multivariate statistical approach. In Gravel Bed Rivers 6 - From process understanding to river restoration, Ergenzinger P, Habersack H, Hoey T, Piégay H, Rinaldi M (eds). Elsevier: Oxford

Jervis J. 1945. The route to the North. John Howe's journey of 1820. Journal and Proceedings of the Royal Australian Historical Society 31: 276-281.

Knighton D. 1998. Fluvial Forms \& Processes. Arnold: London.

Leopold LB, Maddock TJ. 1953. The hydraulic geometry of stream channels and some physiographic implications. United States Geological Survey Professional Paper 252.

Magilligan FJ, McDowell PF. 1997. Stream channel adjustments following elimination of cattle grazing. Journal of the American Water Resources Association 33(4): 867-878.

Mitchell TL. 1823. Map of the Surveyed part of Hunters River. State Archives Auhority of NSW.

Moriarty EO. 1870. Floods in the Hunter: Progress Report. Government Printer.

Nanson GC. 1986. Episodes of vertical accretion and catastrophic stripping; a model of disequilibrium flood-plain development. Geological Society of America Bulletin 97(12): 1467-1475.

Nanson GC, Doyle C. 1999. Landscape stability, Quaternary climate change and European degradation of coastal rivers in southeastern Australia. In Proceedings of the Second Australian Stream Management Conference, Rutherfurd I, Bartley R (eds). Adelaide, February 8-11; 473 - 479.

Newson M. 1980. The geomorphological effectiveness of floods - a contribution stimulated by two recent events in mid-Wales. Earth Surface Processes and Landforms. 5(1): 1-16.

Northcote KH. 1979. A Factual Key for the Recognition of Australian Soils. Rellim Technical Publications Pty. Ltd.: Coffs Harbour.

NSW Water Resources Commission. 1984. Muswellbrook Flood Inundation Map - Hunter River. D. West Government Printers: NSW.

Olley JM, Wasson RJ. 2003. Changes in the flux of sediment in the Upper Murrumbidgee catchment, Southeastern Australia, since European settlement. Hydrological Processes 17(16): 3307-3320.

Page K, Frazier P, Pietsch T, Dehaan R. in press. Channel Change following European settlement: Gilmore Creek, southeastern Australia. Earth Surface Processes and Landforms.

Peake T. 2003. Hunter Bushland Resource Kit, Hunter. Southward Press: Sydney.

Poole G. 2002. Fluvial landscape ecology: addressing uniqueness within the river discontinuum. Freshwater Biology 47: 641-660. 
Prosser IP. 1990. Fire, Humans and Denudation at Wangrah Creek, Southern

Tablelands. Australian Geographical Studies 28: 77-95.

Prosser IP, Rutherfurd ID, Olley JM, Young WJ, Walbrink PJ, Moran CJ. 2001. Large-scale patterns of erosion and sediment transport in rivers networks, with examples from Australia. Freshwater and Marine Research 52: 1-99.

Raine A, Gardiner J. 1994. Channel stabilisation techniques and assessment. In Use and Management of Native Vegetation for River bank Stabilisation and Ecological Sustainability, Raine A, Gardiner J (eds). Milestone and Final Report.

Raine A, Gardiner J. 1995. Guidelines for the ecologically sustainable management of rivers and riparian vegetation. RWRRDC Occasional Paper Series no 03/95.

Rankin D. 1982. Stabilising stream channels by river training and interaction with the environment. Civil Engineering Transactions of Institution of Engineers Australia CE24: 135-142.

Richards K. 1982. Rivers: Form and Process in Alluvial Channels. Methuen: London.

Rinaldi M. 2003. Recent channel adjustments in alluvial rivers of Tuscany, central Italy. Earth Surface Processes and Landforms 28(6): 587-608.

Rusomji P, Olley J, Chappell J. 2006. Holocene valley aggradation driven by river mouth progradation: examples from Australia. Earth Surface Processes and Landforms 31(12): 1510-1524.

Rutherfurd I. 2000. Some human impacts on Australian stream channel morphology. In River management the Australasian experience, Brizga SO, Finlayson BL (eds). Wiley: Chichester; 11-49.

Schumm SA. 1969. River metamorphosis. Journal of Hydraulics Division Proceedings of the American Society of Civil Engineers 95: 255-273.

Schumm SA. 1979. Geomorphic thresholds: the concept and its applications. Transactions Institute British Geographers 4: 485-515.

Spink AM. 2006. An Interdisciplinary Perspective of River Rehabilitation and Management Activities in the Upper Hunter Catchment, New South Wales. MSc (Hons) Thesis: Macquarie University, Sydney.

Thomas MF. 2001. Landscape sensitivity in time and space - an introduction. Catena 42: 83-98.

Trimble SW, Mendel AC. 1995. The cow as a geomorphic agent - A critical review. Geomorphology 13: 233-253.

van Niekerk AW, Heritage GL, Broadhurst LW, Moon BP. 1999. Bedrock anastomosing channel systems: Morphology and dynamics of the Sabie River, Mpumulanga Province, South Africa. In Varieties of Fluvial Form, Miller AJ, Gupta A (eds). John Wiley and Sons: Chichester; 33-51.

Warner RF. 1987. The impacts of alternating flood- and drought-dominated regimes on channel morphology at Penrith, NSW, Australia. IAHS Special Publication 168: 327-338.

Wasson RJ, Olive LJ, Roswell CJ. 1996. Rates of erosion and sediment transport in Australia. In Erosion and Sediment Yield: Global and Regional Perception, Walling DE, Webb BW (eds). IAHS Publication 236: 139-148. 
Werrity A, Leys KF. 2001. The sensitivity of Scottish rivers and upland valley floors to recent environmental change. Catena 42: 251-273.

Wolfenden B, Mika S, Boulton A, Ryder D. 2005. Assessing change in riverine organic matter dynamics in the Hunter River, NSW, over the last 200 years: implications for stream restoration. In Proceedings of the Fourth Australian Stream Management Conference, Rutherfurd I, Wiszniewski I, Askey-Doran M, Glazik R (eds). Launceston, Tasmania; 697-703.

Wolman MG, Gerson R. 1978. Relative scales of time and effectiveness of climate in watershed geomorphology. Earth Surface Processes and Landforms 3(2): 189-208.

Wood WA. 1972. Dawn in the valley. Wentworth Books: Sydney. 


\section{Table captions}

Table 1 - Average modal grainsize distribution of proximal floodplains for each zone in the study reach and the pre-European sinuosity of each zone as measured on the 1883 Parish map.

Table 2 - Age and depth of charcoal samples taken from the palaeochannel and cut-off trenches

Table 3 - Changes to spatial area of instream geomorphic units between 1938 and 2004 
Table 1

\begin{tabular}{|c|c|c|c|}
\hline Zone & $\begin{array}{c}\text { Type of } \\
\text { Adjustment }\end{array}$ & $\begin{array}{c}\text { Average Modal Grainsize } \\
(\boldsymbol{\mu m})\end{array}$ & $\begin{array}{c}\text { Sinuosity in } \\
\mathbf{1 8 8 3}\end{array}$ \\
\hline $\mathbf{1}$ & High & 46.46 & 1.91 \\
\hline $\mathbf{2}$ & Intermediate & 144.20 & 1.31 \\
\hline $\mathbf{3}$ & High & 102.03 & 1.48 \\
\hline $\mathbf{4}$ & Low & 179.01 & 1.04 \\
\hline $\mathbf{5}$ & Intermediate & 108.71 & 1.11 \\
\hline $\mathbf{6}$ & Low & 116.35 & 1.06 \\
\hline $\mathbf{7}$ & High & 48.02 & 2.24 \\
\hline
\end{tabular}


Table 2

\begin{tabular}{|c|c|c|c|c|}
\hline $\begin{array}{c}\text { Sample } \\
\text { number }\end{array}$ & Sample Location & $\begin{array}{c}\text { Depth } \\
(\mathbf{m})\end{array}$ & $\begin{array}{c}\text { Callibrated Age } \\
(\mathbf{B P})\end{array}$ & Error \\
\hline Wk 13660 & Cow trench channel fill & 2.35 & 2210 & \pm 38 \\
\hline Wk 13661 & Cow trench channel fill & 0.98 & 261 & \pm 42 \\
\hline Wk 13662 & $\begin{array}{r}\text { Floodplain material adjacent to } \\
\text { Cow trench }\end{array}$ & 2.95 & 1263 & \pm 46 \\
\hline Wk 13663 & $\begin{array}{r}\text { Floodplain material adjacent to } \\
\text { Cow trench }\end{array}$ & 3.55 & 1307 & \pm 46 \\
\hline Wk 13664 & $\begin{array}{c}\text { Floodplain material adjacent to } \\
\text { Bengalla Road Trench }\end{array}$ & 5.40 & 4282 & \pm 49 \\
\hline
\end{tabular}


Table 3

\begin{tabular}{|c|c|c|c|c|c|c|c|}
\cline { 2 - 8 } \multicolumn{1}{c|}{} & \multicolumn{7}{c|}{ Percentage of Macrochannel area } \\
\hline & $\mathbf{1 9 3 8}$ & $\mathbf{1 9 5 5}$ & $\mathbf{1 9 6 9}$ & $\mathbf{1 9 7 9}$ & $\mathbf{1 9 8 9}$ & $\mathbf{1 9 9 8}$ & $\mathbf{2 0 0 4}$ \\
\hline Unit Lateral & 1.97 & 0.00 & 0.55 & 1.53 & 0.89 & 0.70 & 0.61 \\
\hline Compound Lateral & 3.84 & 3.72 & 3.24 & 3.38 & 2.24 & 2.33 & 1.22 \\
\hline Unit Point & 0.86 & 0.53 & 0.82 & 3.57 & 0.09 & 0.00 & 0.00 \\
\hline Compound Point & 2.81 & 26.53 & 14.20 & 5.41 & 13.04 & 13.06 & 10.58 \\
\hline Diagonal & 0.00 & 0.00 & 0.00 & 0.00 & 0.00 & 0.00 & 0.03 \\
\hline Mid Channel & 0.69 & 0.73 & 0.17 & 0.39 & 0.14 & 0.22 & 0.27 \\
\hline Island & 0.00 & 0.00 & 0.00 & 0.00 & 0.00 & 0.00 & 0.03 \\
\hline Total Bars & $\mathbf{1 0 . 1 6}$ & $\mathbf{3 1 . 5 1}$ & $\mathbf{1 8 . 9 6}$ & $\mathbf{1 4 . 2 7}$ & $\mathbf{1 6 . 4 0}$ & $\mathbf{1 6 . 3 2}$ & $\mathbf{1 2 . 7 4}$ \\
\hline Benches & $\mathbf{5 6 . 7 9}$ & $\mathbf{4 2 . 8 3}$ & $\mathbf{5 7 . 8 5}$ & $\mathbf{6 4 . 5 1}$ & $\mathbf{6 2 . 9 5}$ & $\mathbf{6 3 . 3 2}$ & $\mathbf{6 7 . 3 5}$ \\
\hline Total Bars \& & $\mathbf{6 6 . 9 6}$ & $\mathbf{7 4 . 3 4}$ & $\mathbf{7 6 . 8 1}$ & $\mathbf{7 8 . 7 8}$ & $\mathbf{7 9 . 3 5}$ & $\mathbf{7 9 . 6 4}$ & $\mathbf{8 0 . 0 9}$ \\
\hline Benches & $\mathbf{3 3 . 0 4}$ & $\mathbf{2 5 . 6 6}$ & $\mathbf{2 3 . 1 9}$ & $\mathbf{2 1 . 2 2}$ & $\mathbf{2 0 . 6 5}$ & $\mathbf{2 0 . 3 6}$ & $\mathbf{1 9 . 9 1}$ \\
\hline Low Flow & & & & &
\end{tabular}




\section{Figure captions}

Figure 1 Location of the Hunter catchment and study reach

Figure 2 (a) Hydrograph for the Muswellbrook Bridge gauge 1907 - 2006. This monthly maximum flow record was reconstructed utilising flow data from the Muswellbrook Weir gauge to improve inaccurate data at the bridge during the 1950's and 1960's, resulting from flood induced cross section changes, (b), History of major floods at Muswellbrook 1806 - 1980. This graph shows the gauge height of individual significant floods and is a compilation of data from the Muswellbrook Bridge gauge as well as historical reports and data extrapolated from Maitland and Singleton gauges. As European settlement in the Upper Hunter didn't begin until 1824, flows prior to this time are extrapolated estimates only and may not reflect true flows. This graph indicates the effects of Glenbawn Dam on each flood height so that floods may be compared, (c) Discharge curve for the Muswellbrook gauge based on data from $1892-1995$. The current curve shows the effects of Glenbawn Dam on daily discharge.

Figure 3 Cross sections and sedimentology of three abandoned channels adjacent to the contemporary study reach.

Figure 4 Geological and engineered controls on geomorphic adjustment in the study reach. Each pie graph shows the proportion of each type of works that occurred for a particular zone of adjustment. The number of works per unit length is noted below each pie graph and is reflected in the size of each graph, so that the proportion of the total works in the study reach can be compared for each adjustment zone.

Figure 5 (a) Schematic cross section of the contemporary channel in an intermediate adjustment zone, (b) Contemporary macrochannel and low flow channel alignment, showing the various zones of adjustment and cut-off locations, (c) Table describing the width and geomorphic units present in each of 
the zones of adjustment, (d) Graph of the variability in macrochannel width along the macrochannel length.

Figure 6 Conceptual model showing the change in morphodynamic relationships from the pre-European condition to the contemporary condition in (a) low, (b) intermediate and (c) high adjustment zones. All drawings show low flow stage conditions.

Figure 7 Summary of macrochannel and low flow channel planform change at various time slices between 1883 and 2004.

Figure 8 Photograph of the study reach in zone 7 looking downstream from the right bank, taken in 1951 (note distinct lack of riparian vegetation)

Figure 9 Conceptual model of the various influences affecting the timing of changes in the study reach. Rates of change are indicative only.

Figure 10 Conceptual model showing the phases of change in the study reach. Cross section a-a shows a proposed channel alignment prior to the last major avulsion. Section $b-b$ shows a proposed channel alignment after the last major avulsion. Exact timing of this avulsion is unknown but dating indicates it was sometime between 2600 and 260 years BP. Section c-c shows a typical cross section after a cut-off. Dating indicates that the Cow trench cut-off could be no older than 1300 years (and was more likely around $260 \mathrm{yrs}$ BP) and parish map analysis indicates the most recent (Kehua cut-off) happened prior to 1918. Sections $d-d$, e-e and f-f show the phases of channel transformation that have occurred since European settlement. 